\title{
Legen som skalv på hendene mens han sydde
}

\author{
Jeg har sydd 2891 sting. Jeg har kuttet og kuttet og kuttet, tatt flere titalls overdoser, \\ som regel fordi jeg var så utrolig sinna og så utrolig trist og ikke visste hva jeg skulle \\ gjøre for å kunne holde ut. En time til som levende, en time til med alt det vonde.
}

Å kutte var for meg, i det vonde og ensomme, en måte å søke hjelp på. Det var en måte å gråte på, «se, det blør, jeg gråter». Og det er helt rett, jeg gråt på denne måten med et altfor stort volum, og det kom ikke ut eller frem på en hensiktsmessig måte, men det var i alle fall et første forsøk, helt diametralt forskjellig fra mitt liv frem til jeg var flerogtjue, der det bare var: «Klar deg selv».

Dere må skjønne. Alle som kommer borti folk som skader seg, må skjønne: Å kutte seg er en innrømmelse, en skammelig innrømmelse, om at man trenger andre. «Ja, vær så snill å hjelp meg, jeg trenger andre. Jeg innrømmer det.»

Da er det leit og vondt å bli møtt på legevakten med nesten bare sinne, med legenes utbrudd som: «Er du her igjen, ta deg sammen!», «Nå må du slutte å tulle!», «Vi kan ikke bruke all tiden vår på deg. Ser du ikke hvor mange det er som venter ute på venterommet?», «Du må slutte, nå har jeg stått her og sydd deg i to og en halv time, det er fullt av folk som venter, du kan ikke holde på sånn». Må jeg ikke forstå det som «Du er en dritt som vi helst ville ha vært foruten. De andre på venterommet er ti ganger viktigere enn deg»? En lege hilste ikke på meg engang, bare rigget seg til og snakket i over en time med sykepleieren om hytta si, mens jeg bare var noe som lå der, et herk, ikke noe. Skal jeg klare å slutte å kutte meg, må jeg være verdt noe som menneske, ikke bare oppleve at jeg er noe man helst vil bli fortest mulig ferdig med. Det er trist å være en man bare vil bli kvitt.

\section{Min måte å gråte på}

Blodet og kuttingen var min måte å gråte på. Man er ikke så opptatt av selve tårene når noen gråter. Men man bryr seg - intuitivt og fint - om hvorfor. Hvorfor var så mange ganger mine tårer kun til bry? Hvorfor tar ikke legene på legevakten seg bare bittelitt ekstra tid til å finne ut hvorfor, eller, om jeg er taus og utafor, sende meg videre til psykiatrisk (der det tross alt er bedre tid). Hvorfor kan de ikke spørre om jeg får hjelp der? Når så motet mitt sviktet i forhold til det å be om hjelp på psykiatrisk, var det faktisk godt de gangene noen på legevakten agerte som tredje instans og sa: «Men jeg vil at du skal dit» og «Herlighet, hva er det de driver med der borte, du må da få hjelp.» Noen ganger er sånne ord så verdifulle. Noen vil meg vel. Eller bare det gode i en lege som så alle arrene oppover og sa: «Jeg ser du har hatt det vanskelig», ikke som et spørsmål, enten nysgjerrig eller idiotisk, men som en bekreftelse, en bekreftelse på at jeg ble sett - og som derfor sendte meg videre.

For det ble mye frem og tilbake - trass $i$ at jeg hadde åpen retur og bare kunne komme. Jeg torde jo ikke spørre om innleggelse, med ord. Opplagt - fordi jeg da måtte tro på, virkelig tro på, at jeg hadde verdi, ikke som ytende menneske, men også som sårbar og skadet og redd. Men også fordi jeg var redd de på psykiatrisk ikke ville hjelpe når de i starten skrev meg ut, nesten uansett hvor suicidal jeg var og ikke minst, ufattelig redd og ensom. De ville at jeg skulle be om hjelp, de ville at jeg skulle lære å kjenne etter. Behovet er ikke like stort hele tiden. Men: Det er ganske vanskelig å spørre om hjelp når man nettopp har fătt høre at det beste er om du ikke er hos oss, vi kan ikke ha deg her hele tiden. Og ja, det ble mange runder, og alvorlige runder, før jeg skjønte mer av det. Så jeg kuttet. Og satt etterpå hjemme og telte stingene. De vitnet om at noe kunne gro, om at noen hadde gjort en innsats for å hjelpe meg. Men jeg forstår også at kutting gjør inntrykk, nesten uansett hvor profesjonell man forsøker å være. Som psykologen min en gang sa: «Det gjør noe med oss som bryr oss om deg, at du er voldelig mot deg selv.»

En lege bekreftet det kompliserte ved så fint å si: «Å sy deg er lett, å hjelpe deg er vanskelig.» En sykepleier hjalp også til med å realitetsorientere ved å si: «Det er ganske skremmende å se, også for oss som jobber her, skjønner du det?» Inni meg tenkte jeg: Nei. Nei, jeg skjønner ikke det. Jeg har kuttet og kuttet og kuttet, nei, jeg skjønner ikke det. For å kunne skjønne det trenger jeg reaksjoner, jeg trenger virkelighet, jeg trenger at noen snakker med meg. Jeg trenger at det ikke blir oversett. Jeg trenger noen som er mennesker, direkte og som spør hva det er, hva som er galt denne gangen. Jeg trenger den legen på legevakten, han som skalv på hendene mens han sydde. For han var jeg ikke rutine. Sårene mine, smerten min berørte ham. Og det var utrolig godt å kjenne, å ta med ut.

\section{Kristin Ribe \\ kristin_ribe@hotmail.com}

Manuskriptet ble mottatt 3.7. 2008 og godkjent 18.9. 2008. Medisinsk redaktør Siri Lunde. 